\title{
The Degradation of Polygalacturonic Acid by Rumen Ciliate Protozoa
}

\author{
By G. S. COLEMAN,* DEBORAH C. SANDFORD AND S. BEAHON \\ Biochemistry Department, Agricultural Research Council, Institute of Animal \\ Physiology, Babraham, Cambridge CB2 $4 A T$
}

(Received 1 April 1980)

\begin{abstract}
The depolymerase activity of cell-free extracts of nine species of rumen ciliate protozoa and two mixed protozoal preparations, grown in vivo and in vitro, towards polygalacturonic acid was examined. The highest activity was found with Eremoplastron bovis and Ostracodinium obtusum bilobum while there was none in the spined or spineless forms of Entodinium caudatum and little in Polyplastron multivesiculatum. On the basis of the rapid drop in viscosity, inhibition by EDTA and the production of u.v.-absorbing material, the enzymes from all active species were designated as endopectate lyases (EC 4.2.2.2) although some polygalacturonase may be present. Neither pectin nor polygalacturonic acid supported the survival or growth of any of the protozoal species tested.
\end{abstract}

\section{INTRODUCTION}

There are several reports (e.g. Wright, 1960, 1961; Abou Akkada \& Howard, 1961) that rumen ciliate protozoa contain pectin esterase and enzymes that depolymerize polygalacturonic acid. There is little information on the activity possessed by individual protozoal species although Mah \& Hungate (1965) reported that Ophryoscolex purkynei contained polygalacturonate transeliminase (now called pectate lyase). This produced dehydrogenogalacturonyl digalacturonic acid (altered trimer) and dehydrogenogalacturonyl galacturonic acid (altered dimer) as final products and was similar to the bacterial enzyme studied by Hasegawa \& Nagel (1962). The present paper records the activities against polygalacturonic acid of cell-free supernatant fluids obtained after the disruption of pure and mixed suspensions of rumen ciliates, grown in vivo and in vitro, and provides evidence that the enzymes are lyases.

\section{METHODS}

Protozoa. Sheep (Clun Forest wethers) containing single protozoal species were obtained by defaunation of the rumen by the method of Orpin (1977) followed by the introduction of a suspension of a single protozoal species isolated from the rumen and grown in vitro as described by Coleman (1978). Mixed rumen protozoa were taken from animals with a normal A-type population (Eadie, 1962, 1967). Entodinium bursa and the spined form of Entodinium caudatum were grown together in the rumen as the former would only grow in the presence of the latter and the latter only formed spines in the presence of the former. The sheep were fed once a day on hay chaff $(800 \mathrm{~g})$ and oats $(100 \mathrm{~g})$ and rumen contents were removed via a cannula $17 \mathrm{~h}$ after feeding. The preparation of washed suspensions of protozoa and the separation of a mixed population into fractions containing small or large protozoa were carried out as described by Coleman \& Sandford (1979).

Protozoa were grown in vitro as described by Coleman (1978) and harvested as described by Coleman (1969) except that mineral salt solution $\mathrm{D}$ [containing $\left(\mathrm{g}^{-1}\right): \mathrm{K}_{2} \mathrm{HPO}_{4}, 6 \cdot 3 ; \mathrm{KH}_{2} \mathrm{PO}_{4}, 5 \cdot 0 ; \mathrm{NaCl}, 0.65$; $\mathrm{CaCl}_{2}$ (dried), 0.045; $\mathrm{MgSO}_{4} .7 \mathrm{H}_{2} \mathrm{O}, 0.09$ ] was used throughout. The protozoa were finally suspended in water (for disruption) or in salt solution $\mathrm{D}$ (for experiments with living protozoa) when $\mathrm{N}_{2} / \mathrm{CO}_{2}$ (95:5, $\mathrm{v} / \mathrm{v}$ ) was bubbled through the suspension for $2 \mathrm{~min}$ before addition to the incubation medium. 
Disruption of protozoa by sonication. The tube containing the protozoal suspension was immersed in an ultrasonic cleaning bath (average output $40 \mathrm{~W}$, frequency $80 \mathrm{kHz}$ ) at room temperature until no protozoa could be detected microscopically (Coleman \& Laurie, 1977). The crude homogenate was then centrifuged $\left(5500 \mathrm{~g}, 20 \mathrm{~min}, 4^{\circ} \mathrm{C}\right.$ ) and enzyme activity was measured in the supernatant fluid (cytoplasmic fraction).

Pectate lyase assay. Pectate lyase was assayed by following the appearance of reducing material using polygalacturonic acid (Sigma, grade III from orange) as substrate. The reaction mixture contained $2 \cdot 0 \mathrm{ml} 0 \cdot 1$ $\mathrm{M}-N$-t 1 is(hydroxymethyl)methyl-2-aminoethanesulphonic acid (TES, $\mathrm{pH} \mathrm{8.5),0.02}$ to $3.6 \mathrm{ml}$ polygalacturonic acid solution, $0.4 \mathrm{ml}$ of a suitable dilution of the enzyme in TES buffer, and 0 to $3.58 \mathrm{ml}$ water to give a final volume of $6.0 \mathrm{ml}$. Samples $(1.0 \mathrm{ml})$ were removed at intervals $(30 \mathrm{~min})$ and assayed for reducing material by Nelson's (1944) method using D-galacturonic acid (Sigma) as standard. The polygalacturonic acid solution was prepared by dialysis of a $1 \%(w / v)$ solution (neutralized with $\mathrm{NaOH}$ ) for $48 \mathrm{~h}$ against two changes of distilled water. The polygalacturonic acid content of the product was determined by hydrolysis with $2 \%$ (v/v) concentrated $\mathrm{HNO}_{3}$ for $11 \mathrm{~h}$ (Jermyn, 1955) and assay of the liberated galacturonic acid. The rate of the enzyme reaction was constant for at least $1.5 \mathrm{~h}$ and was proportional to enzyme (from Eremoplastron bovis) concentration over a 30 -fold range at a substrate concentration of $0.8 \mathrm{~mm}$ (with respect to galacturonic acid). Where sufficient protozoal extract was available, the rate of reaction was measured at eight substrate concentrations and the maximum velocity and $K_{\mathrm{m}}$ were determined by extrapolation to the ordinate and abscissa, respectively, of a double reciprocal plot of rate against substrate concentration. Where insufficient extract was available, the rate was measured in the presence of $0.8 \mathrm{mM}$ (with respect to galacturonic acid) polygalacturonic acid only. Activity is expressed as pmol galacturonic acid produced $\mathrm{h}^{-1}$ protozoon $^{-1}$ or (ng protein) $)^{-1}$.

Incubation conditions for experiments with living protozoa. The mixture contained $1.0 \mathrm{ml}$ protozoal suspension $\left(10^{4}\right.$ to $\left.10^{5} \mathrm{ml}^{-1}\right)$ or salt solution $\mathrm{D}, 0.2 \mathrm{ml} 1 \%(\mathrm{w} / \mathrm{v})$ pectin or polygalacturonic acid (neutralized to $\mathrm{pH} 7$ with $\mathrm{NaOH})$ or water, and $0.05 \mathrm{ml} 1 \%(\mathrm{w} / \mathrm{v})$ ampicillin. After inoculation, $\mathrm{N}_{2} / \mathrm{CO}_{2}(95: 5)$ was bubbled through the medium for $15 \mathrm{~s}$, the tube was sealed with a rubber bung and incubated at $39^{\circ} \mathrm{C}$. At the end of the incubation $\left(0\right.$ to $6 \mathrm{~h}$ ) the protozoa were sedimented by centrifuging $\left(200 \mathrm{~g}, 30 \mathrm{~s}, 15^{\circ} \mathrm{C}\right)$ and samples of the supernatant fluid were assayed for reducing sugars.

$V$ iscosity measurements. These were made in an Ostwald viscometer at $20^{\circ} \mathrm{C}$. Fifteen $\mathrm{ml}$ of $1 \%(\mathrm{w} / \mathrm{v})$ polygalacturonic acid (neutralized with $\mathrm{NaOH}$ ) in $0.02 \mathrm{M}$-TES $\left(\mathrm{pH} 8.5\right.$ ) was incubated at $39{ }^{\circ} \mathrm{C}$ with $0.05 \mathrm{ml}$ enzyme preparation or water. At intervals, samples were taken for the estimation of reducing material (as above) and, after cooling to $20^{\circ} \mathrm{C}$, measurements were made of the viscosity of the medium.

Paper chromatography. The following solvents were used: $\mathbf{A}$, ethyl acetate/pyridine/acetic acid/water (5:5:1:3, by vol.) (Nagel \& Vaughn, 1961); B, ethyl acetate/acetic acid/water $(2: 1: 2$, by vol., upper phase); C, propan-1-ol/ethyl acetate/water (24:13:7, by vol.); D, butan-2-ol/formic acid/water (7:1:2, by vol.).

Other procedures. Protein was determined by the Lowry method of using bovine serum albumin as standard. The number of protozoa was determined as described by Coleman et al. (1976).

\section{RESULTS}

\section{Effect of $\mathrm{pH}$ on activity}

In the presence of $0.033 \mathrm{M}$-TES or glycine buffers the optimum $\mathrm{pH}$ of the polygalacturonate depolymerase in all the Entodiniomorphid protozoa tested, as determined by the drop in viscosity or production of reducing material, was about 8.5 , but by the latter method the activity was over $80 \%$ of the maximum from $\mathrm{pH} 7.7$ to 10.0 (Fig. 1). At the $\mathrm{pH}$ of the growth medium (6.8) the activity was only $30 \%$ and at the $\mathrm{pH}$ of the cell contents $(6.0$; Weineck, 1934$)$ it was only $14 \%$ of the maximum value.

\section{Activity of individual protozoal species}

All species tested, except for Entodinium caudatum, contained depolymerase in the cytoplasmic fraction when grown in vivo or in vitro (Table 1). As the activity of the crude homogenate was the same before and after removal of the bacteria by centrifugation, none of the activity in the protozoa was due to intracellular bacteria. Eremoplastron bovis and Ostracodinium obtusum bilobum contained the most activity per ng protein and Entodinium bursa and Polyplastron multivesiculatum the least. Similar results were obtained whether the protozoa were grown in vitro or isolated from the rumen. The activity of Epidinium ecaudatum caudatum was similar whether it was grown on ground wheat in the 


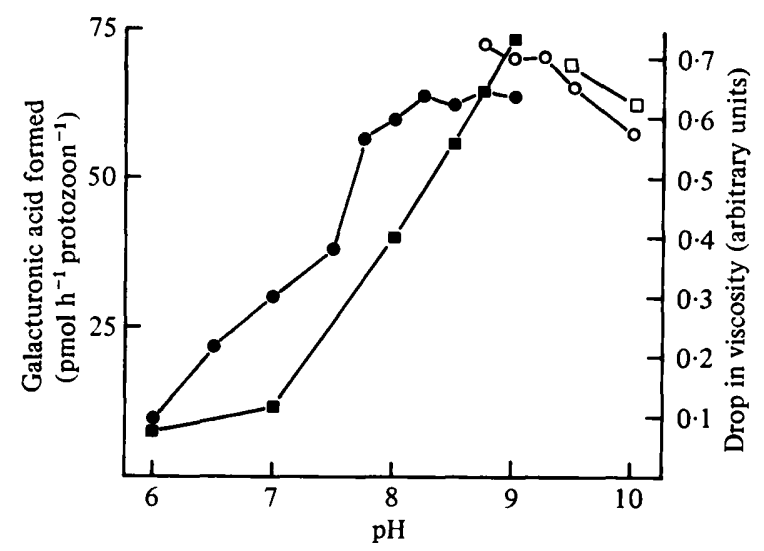

Fig. 1. Effect of $\mathrm{pH}$ on the depolymerization of polygalacturonic acid by cell-free extracts of Eremoplastron bovis as determined by reducing sugar assay using TES (O) or glycine $(O)$ buffers and drop in viscosity using TES ( $\square$ ) or glycine $(\square)$ buffers.

\section{Table 1. Pectate lyase activity of cytoplasmic fractions from rumen ciliate protozoa}

Enzyme activities are expressed as pmol galacturonic acid produced $\mathbf{h}^{-1}$ protozoon ${ }^{-1}$ or, in parentheses, as pmol $\mathrm{h}^{-1}$ (ng protein) $)^{-1} . V_{\max }$ and $K_{\mathrm{m}}$ values were determined from double reciprocal plots.

\begin{tabular}{|c|c|c|c|c|c|c|}
\hline \multirow[b]{2}{*}{ Protozoon } & \multirow{2}{*}{$\begin{array}{l}\text { Growth } \\
\text { conditions* }\end{array}$} & \multicolumn{4}{|c|}{ Enzyme activity } & \multirow{2}{*}{$\underset{(\mathrm{mM})}{K_{\mathrm{m}}}$} \\
\hline & & \multicolumn{2}{|c|}{ At $0.8 \mathrm{~mm}$} & \multicolumn{2}{|c|}{$V_{\max }$} & \\
\hline $\begin{array}{l}\text { Diploplastron affine } \\
\text { Entodinium bursa }\end{array}$ & $\begin{array}{l}T \\
V \\
T\end{array}$ & $\begin{array}{c}115 \\
4 \cdot 5 \\
2 \cdot 88\end{array}$ & $\begin{array}{l}(8 \cdot 2) \\
(0 \cdot 87) \\
(0 \cdot 56)\end{array}$ & 270 & (19) & 0.20 \\
\hline Entodinium caudatum & & & & & & \\
\hline Spined form & V & 0 & & & & \\
\hline Spineless form & $\mathbf{T}$ & 0 & & & & \\
\hline Epidinium ecaudatum caudatum & $T$ & $\begin{array}{l}61 \cdot 8 \\
45.9\end{array}$ & $\begin{array}{l}(3 \cdot 4) \\
(2 \cdot 5)\end{array}$ & $\begin{array}{c}71 \cdot 6 \\
108\end{array}$ & $\begin{array}{l}(4 \cdot 0) \\
(6 \cdot 0)\end{array}$ & $\begin{array}{l}0.075 \\
0.58\end{array}$ \\
\hline & $\mathrm{V}$ & $48 \cdot 5$ & $(2 \cdot 7)$ & $73 \cdot 2$ & (4.1) & 0.25 \\
\hline Eremoplastron bovis & $\mathbf{T}$ & $51 \cdot 5$ & $(11 \cdot 4)$ & & & \\
\hline & $\mathrm{V}$ & 67.0 & (14.9) & 296 & $(65 \cdot 8)$ & 0.060 \\
\hline Eudiplodinium maggii & $T$ & 159 & $(6 \cdot 6)$ & 237 & $(9 \cdot 9)$ & $0 \cdot 30$ \\
\hline & $\mathrm{V}$ & 113 & $(4 \cdot 7)$ & 263 & $(10 \cdot 9)$ & 0.44 \\
\hline Ophryoscolex caudatus & $\mathbf{T}$ & 92.8 & $(2 \cdot 1)$ & 665 & $(14 \cdot 7)$ & $0 \cdot 27$ \\
\hline & $\mathrm{V}$ & 113 & $(2 \cdot 5)$ & 371 & $(8 \cdot 2)$ & $0 \cdot 25$ \\
\hline Ostracodinium obtusum bilobum & $\mathbf{T}$ & 252 & $(20 \cdot 1)$ & 495 & $(40 \cdot 2)$ & 0.072 \\
\hline & $\mathrm{V}$ & 108 & $(8 \cdot 8)$ & 268 & $(21 \cdot 6)$ & 0.13 \\
\hline Polyplastron multivesiculatum (+ epidinia) & & 10 & $(0 \cdot 15)$ & & & \\
\hline Mixed large protozoa & $\mathrm{V}$ & 17 & $(0.46)$ & 21 & $(0 \cdot 6)$ & $0 \cdot 19$ \\
\hline $\begin{array}{l}\text { Mixed small protozoa (Dasytricha } \\
\text { ruminantium) }\end{array}$ & $\mathrm{V}$ & 11 & $(1 \cdot 1)$ & & & \\
\hline
\end{tabular}

${ }^{*} \mathrm{~T}$, Grown in vitro; $\mathrm{V}$, grown in vivo. $\quad$ Grown in the presence of $\beta$-sitosterol instead of grass.

presence of dried grass or on $\beta$-sitosterol when the amount of pectic material engulfed would be less. The activity of the small and large protozoal fractions prepared from a typical A-type population (Eadie, 1962, 1967) was low. The small fraction contained only small Entodinium spp. and Dasytricha ruminantium and as the former do not contain the enzyme, the results in Table 1 have been calculated on the assumption that only the latter was active.

Washed suspensions of Epidinium ecaudatum caudatum, Eremoplastron bovis, Eudiplodinium maggii and Ophryoscolex caudatus incubated anaerobically in salt solution D (pH 6.8) in the presence of $1.6 \mathrm{mg}$ polygalacturonic acid $\mathrm{ml}^{-1}$ all produced reducing material but the rates were only $2 \cdot 3 \%, 0 \cdot 1 \%, 0.3 \%$ and $4.3 \%$ of that obtained with the cytoplasmic 
fraction at $\mathrm{pH} 8.5$. The survival time of these protozoal suspensions was the same (24 to $36 \mathrm{~h}$ ) in the presence or absence of polygalacturonic acid although it was increased to 48 to $72 \mathrm{~h}$ in the presence of ground wheat. These protozoal species were therefore unable to use the digestion products from polygalacturonic acid for survival.

\section{Requirement for metal ions}

There was no loss of activity on dialysis of the cytoplasmic fraction from any of the protozoa against distilled water or 1 or $10 \mathrm{mm-EDTA}$, and the activity of the original or dialysed material was not increased in the presence $1 \mathrm{mM} \mathrm{Mg}^{2+}$ or $\mathrm{Co}^{2+}$. However, all the enzyme preparations were completely inhibited by EDTA $(0.5 \mathrm{mM})$ as found with bacterial pectate lyases (Rombouts, 1972). This inhibition could be reversed (to the extent shown in parentheses for the enzyme from Epidinium ecaudatum caudatum) by the following metal ions (at $1 \mathrm{~mm}): \mathrm{Mg}^{2+}(87 \%), \mathrm{Co}^{2+}(79 \%), \mathrm{Ca}^{2+}(67 \%)$ and $\mathrm{Mn}^{2+}(53 \%)$. Higher or lower concentrations of these ions were less effective. This suggests that the enzyme contains a tightly bound metal ion which can be blocked but not removed by EDTA which, in turn, can be removed from the enzyme by added metal ions.

\section{Reaction mechanism}

The actions of polygalacturonase and the lyase were distinguished by comparison of the rate of appearance of reducing groups, which occurs in the presence of both enzymes, and the appearance of the unsaturated galacturonic acid which is found only in the presence of the lyase and which absorbs at $235 \mathrm{~nm}$. With preparations from all the active protozoa listed in Table 1, the production of reducing material was always associated with an increase in absorption at $235 \mathrm{~nm}$ and both were dependent on the presence of enzyme and substrate and were inhibited by EDTA. Comparison of the results obtained by both methods and using the value of $47001 \mathrm{~mol}^{-1} \mathrm{~cm}^{-1}$ for the molar absorption coefficient of the unsaturated compound (Lee et al., 1970) indicated that $77 \%$ (with Eremoplastron bovis) or $83 \%$ (with Epidinium ecaudatum caudatum) of the reducing groups formed could be accounted for by the action of pectate lyase. Chromatography of the reaction products in solvent $A$ and spraying with ammoniacal silver nitrate showed the presence of galacturonic acid (identified by chromatography in solvents A to D) and other spots of $R_{\text {Gals }} 0.09,(0 \cdot 18), 0.42$, and $(1 \cdot 2)$ or $(1 \cdot 5)$. The spots with $R_{\text {Gals }}$ values shown in parentheses also gave a positive reaction with the periodate/thiobarbiturate spray of Warren (1960), that of $R_{\text {GaIs }} 0 \cdot 18$ staining most deeply. Insufficient material was available for detailed examination of the products but from the spray reactions and by comparison with the results of Nagel \& Vaughn (1961) and Hsu \& Vaughn (1969) they could be, respectively, trigalacturonide, altered trigalacturonide, digalacturonide and two monomers. No spot corresponding to the altered digalacturonide was seen.

The viscosity of polygalacturonate solutions dropped rapidly in the presence of all active fractions; for example, there was a $70 \%$ fall in viscosity with only a $4.4 \%$ breakage of the glycosidic bonds with one Ophryoscolex caudatus preparation. This is taken as evidence that the enzyme in the protozoa is an endo-pectate lyase which preferentially attacks the polygalacturonic acid molecule in the middle. However, it is possible that different enzymes were responsible for the two different effects.

\section{Growth of Eremoplastron bovis and Eudiplodinium maggii in the presence of pectin and polygalacturonic acid}

As these two protozoa, which grow in vitro on dried grass as the sole added source of food, have high activities of pectate lyase, it was of interest to determine if the grass could be replaced by pectin or polygalacturonic acid. On omission of the grass (which is the only added source of food; Coleman et al., 1976) from the medium or its replacement by either substrate, the health of the cultures as determined microscopically declined after $3 \mathrm{~d}$ and 
all the protozoa were dead after $7 \mathrm{~d}$. As the grass was probably supplying other factors apart from acting as a source of energy, experiments were made in which grass was added only every 3 to $5 \mathrm{~d}$. In the absence of any other substrate Eremoplastron bovis died after 3 weeks when grass was fed every fourth day and after 2 weeks when fed every fifth day and the periods could be increased to 9 and 6 weeks, respectively, by the daily addition of 1 drop (approx. $0.07 \mathrm{ml}$ ) of $1 \%(\mathrm{w} / \mathrm{v})$ pectin or polygalacturonic acid to $30 \mathrm{ml}$ culture. Eudiplodinium maggii tolerated starvation better than Eremoplastron bovis and survived for 5 weeks when fed grass only every fifth day. This period was increased to 7 weeks by the daily addition of polygalacturonic acid but not by pectin. The polygalacturonic acid may therefore be utilized to a very limited extent by the protozoa. However, the solubility of both substrates may make them less easily engulfed by the protozoa than grass particles and give a false result.

\section{DISCUSSION}

These experiments show that Entodinium spp. (as reported by Abou Akkada \& Howard, 1961) and Polyplastron multivesiculatum, which require starch for growth, have little or no ability to depolymerize polygalacturonic acid. Epidinium ecaudatum caudatum and Diploplastron affine, which prefer starch but grow poorly on dried grass (Coleman et al., 1976), and Ophryoscolex caudatus, which will only grow on starch, contain intermediate amounts of enzyme, while Eremoplastron bovis, Eudiplodinium maggii and Ostracodinium obtusum bilobum, which prefer grass as a source of food, contain the highest activities. Calculations from the results of Abou Akkada \& Howard (1961) show that the activity in mixed Isotricha spp., which do not attack plant materials, was $0.7 \mathrm{pmol} \mathrm{h}^{-1}$ (ng protein) ${ }^{-1}$ which is lower than that for most of the Entodiniomorphid protozoa. This shows that those protozoa which must engulf appreciable amounts of pectin during feeding on dried grass contain the higher enzyme activities. However, previous studies on gas production by principally mixed protozoal suspensions and the present studies on protozoal survival and growth support the view that pectin and polygalacturonic acid cannot be readily utilized by rumen protozoa. The role in protozoal metabolism of enzymes with a high optimum $\mathrm{pH}$ that hydrolyse these substrates is therefore obscure. Nevertheless, the present results and those of Abou Akkada \& Howard (1961) differ from those of Wright (1960) who followed the change in viscosity of polygalacturonic acid and found an optimum $\mathrm{pH}$ of 6.5 to $7 \cdot 2$ with an extract from a mixture of isotricha and epidinia.

Many rumen bacteria also degrade pectic substances (Prins, 1977) and the large treponemes, Bacteroides ruminicola and Streptococcus bovis, contain pectate lyases (Wojciechowicz, 1971; Ziolecki et al., 1972; Wojciechowicz \& Ziolecki, 1979). As the latter organism could not utilize the degradation products it has been suggested that it degrades the pectin to gain access to the sugars that occur in natural pectins (Ziolecki et al., 1972). The same could be true for the protozoa, but as they all readily utilize starch or cellulose, it is difficult to see that they would gain sufficient sugar from pectin for the process to be energetically worthwhile.

The parallel increase in absorption at $235 \mathrm{~nm}$ and the amounts of reducing sugars, together with the inhibitory effect of EDTA and the high optimum $\mathrm{pH}$, suggest that the enzymes in the rumen ciliates were lyases (Nasuno \& Starr, 1967; Rombouts, 1972) as originally found in bacteria by Hasegawa \& Nagel (1962). However, the products were probably galacturonic acid, altered trimer and altered monomers (such as dehydrogalacturonic acid and 4-deoxy-5-hexulose-uronic acid), as was found with a pseudomonad by Priess \& Ashwell (1963) and rumen treponemes (Wojciechowicz \& Ziolecki, 1979), rather than the altered dimer and altered trimer found by MacMillan \& Vaughn (1964) with Clostridium multifermentans. This suggests that the protozoa contain an enzyme or enzymes with polygalacturonase (Phaff, 1966) and lyase activities or that an enzyme capable of splitting the altered dimer to its component monomers was present. The ciliate enzyme 
also differs from that in Clostridium multifermentans in being an 'endo' rather than an 'exo' enzyme and therefore resembles that in Bacillus polymyxa (Nagel \& Wilson, 1970), for example.

We wish to thank Dr P. Kemp for inserting permanent rumen cannulae into the sheep used to provide rumen contents and Mrs D. J. Reynolds for valuable technical assistance.

\section{REFERENCES}

Abou Akkada, A. R. \& Howard, B. H. (1961). The biochemistry of rumen protozoa. 5. Decomposition of pectic substances. Biochemical Journal 78, 512-517.

Coleman, G. S. (1969). The metabolism of starch, maltose, glucose and some other sugars by the rumen ciliate Entodinium caudatum. Journal of General Microbiology 57, 303-332.

Coleman, G. S. (1978). Rumen Entodiniomorphid protozoa. In Methods of Cultivating Parasites in Vitro, pp. 39-54. Edited by A. E. R. Taylor \& J. R. Baker. London: Academic Press.

Coleman, G. S. \& Laurie, J. I. (1977). The metabolism of starch, glucose, amino acids, purines, pyrimidines and bacteria by the rumen ciliate Polyplastron multivesiculatum. Journal of General Microbiology 98, 29-37.

Coleman, G. S. \& Sandford, D. C. (1979). The engulfment and digestion of mixed rumen bacteria and individual bacterial species by single and mixed species of rumen ciliate protozoa grown in vivo. Journal of Agricultural Science, Cambridge 92, 729-742.

Coleman, G. S., Laurie, J. I., Bailey, J. E. \& Holdgate, S. A. (1976). The cultivation of cellulolytic protozoa isolated from the rumen. Journal of General Microbiology 95, 144-150.

EADIE, J. M. (1962). Inter-relationships between certain rumen ciliate protozoa. Journal of General Microbiology 29, 579-588.

EADIE, J. M. (1967). Studies on the ecology of certain rumen ciliate protozoa. Journal of General Microbiology 49, 175-194.

Hasegawa, S. \& Nagel, C. W. (1962). The characterisation of $\alpha, \beta$ unsaturated digalacturonic acid. Journal of Biological Chemistry 237, 619-621.

Hsu, E. J. \& Vaughn, R. H. (1969). Production and catabolite repression of the constitutive polygalacturonic acid trans-eliminase of Aeromonas liquefaciens. Journal of Bacteriology 98, 172-181.

JERMYN, M. A. (1955). Cellulose and hemicelluloses. In Modern Methods of Plant Analysis, vol. 2, pp. 197-225. Edited by K. Paech \& M. V. Tracey. Berlin: Springer-Verlag.

Lee, M., Miller, L. \& Macmillan, J. D. (1970). Similarities in the action pattern of exopolygalacturonate lyase and pectinase from Clostridium multifermentans. Journal of Bacteriology 103, 595-600.

MaH, R. A. \& Hungate, R. E. (1965). Physiological studies on the rumen ciliate Ophryoscolex purkynei Stein. Journal of Protozoology 12, 131-136.

Macmillan, J.D. \& Vaughn, R. H. (1964). Purification and properties of a polygalacturonic acid trans-eliminase produced by Clostridium multifermentans. Biochemistry 3, 564-572.

Nagel, C. W. \& VaughN, R. H. (1961). The degradation of oligogalacturonides by the polygalacturonases of Bacillus polymyxa. Archives of Biochemistry and Biophysics 94, 328-332.

Nagel, C. W. \& Wilson, T. M. (1970). Pectic acid lyases of Bacillus polymyxa. Applied Microbiology 20, 374-384.

Nasuno, S. \& STarr, M. P. (1967). Polygalacturonic acid trans-eliminase of Xanthomonas campestris. Biochemical Journal 104, 178-185.

Nelson, N. (1944). A photometric adaptation of the Somogyi method for the determination of glucose. Journal of Biological Chemistry 153, 375-380.

OrPIN, C. G. (1977). Studies on the defaunation of the ovine rumen using dioctyl sodium sulphosuccinate. Journal of Applied Bacteriology 43, 309-318.

PhafF, H. J. (1966). $\alpha$-1,4-Polygalacturonide glycanohydrolase (endo-polygalacturonase) from Saccharomyces fragilis. Methods in Enzymology 8, 636-641.

Preiss, J. \& Ashwell, G. (1963). Polygalacturonic acid metabolism in bacteria. 1. Enzymatic formation of 4-deoxy-L-threo-5-hexosulose uronic acid. Journal of Biological Chemistry 238, 1571-1576.

PrINS, R. A. (1977). Biochemical activities of gut micro-organisms. In Microbial Ecology of the Gut, pp. 73-183. Edited by R. T. J. Clarke \& T. Bauchop. New Ycrk: Academic Press.

Rombouts, F. M. (1972). Occurrence and properties of bacterial pectate lyases. Agricultural Research Report 779. Wageningen: Centre for Agricultural Publishing and Documentation.

WARREN, L. (1960). Thiobarbituric acid spray reagent for deoxysugars and sialic acids. Nature, London 186, 237.

WeINECK, E. (1934). Die Celluloseverdauung bei den Cilaten des Wiederkäuermagens. Archiv für Protistenkunde 82, 169-202.

WoJCIECHOWICZ, M. (1971). Partial characterisation of pectinolytic enzymes of Bacteroides ruminicola isolated from the rumen of a sheep. Acta microbiologica polonica A3, 45-50.

Wojciechowicz, M. \& Ziolecki, A. (1979). Pectinolytic enzymes of large rumen treponemes. Applied and Environmental Microbiology 37, 136-142.

Wright, D. E. (1960). Pectic enzymes in rumen protozoa. Archives of Biochemistry and Biophysics 86, 251-254.

Wright, D. E. (1961). Bloat in cattle. 19. The metabolism of pectin by rumen microorganisms. New Zealand Journal of Agricultural Research 4, 203-215.

Ziolecki, A., Tomerska, H. \& Wojciechowicz, M. (1972). Pectinolytic activity of rumen streptococci. Acta microbiologica polonica A4, 183-188. 